\title{
Pengaruh Program Perubahan Perilaku Ibu Hamil (Cerdigi) Berdasarkan Teori ABC (Studi Pendahuluan di Kelurahan Serpong, Tangerang Selatan)
}

\author{
Annisa Septalita* dan Peter Andreas** \\ *Magister Program Studi IImu Kedokteran Gigi Komunitas, Fakultas Kedokteran Gigi, Universitas Indonesia, Jakarta, Indonesia \\ *Departemen Ilmu Kedokteran Gigi Masyarakat, Fakultas Kedokteran Gigi, Universitas Prof. Dr. Moestopo (Beragama), Jakarta, \\ indonesia \\ ** Program Studi IImu Kedokteran Gigi Komunitas, Fakultas Kedokteran Gigi, Universitas Indonesia, Jakarta, Indonesia \\ *JI Salemba Raya no. 4 Jakarta 10430, Indonesia; e-mail: septalitaannisa@yahoo.com
}

\begin{abstract}
ABSTRAK
Kesehatan gigi dan mulut merupakan salah satu hal yang perlu diperhatikan selama kehamilan. Perilaku pemeliharaan kesehatan gigi dan mulut selama hamil masih rendah. Kondisi kesehatan gigi dan mulut ibu hamil yang buruk dapat memberikan dampak, seperti bayi lahir prematur dan berat badan lahir rendah (BBLR). Teori perubahan perilaku ABC berfokus antecedent, behavior, dan consequence. Tujuan penelitian untuk mengetahui perilaku pemeliharaan kesehatan gigi mulut ibu hamil, mengindentifikasi faktor antecedent-nya, melakukan intervensi perubahan behavior-nya (DHE), dan menganalisis consequence perilakunya. Jenis penelitian ini deskriptif dengan desain cross sectional, melibatkan 27 ibu hamil di Kelurahan Serpong, Tangerang Selatan. Pengumpulan data diperoleh melalui wawancara dan kuesioner. Hasil penelitian menunjukkan $100 \%$ (27 responden) menyikat gigi 2x/hari, 44,4\% (12 responden) menggunakan obat kumur $1 \mathrm{x} /$ minggu dan $4 \%$ (1 responden) memeriksakan ke dokter gigi saat hamil. Faktor antecedent tidak memeriksakan ke dokter gigi saat hamil yaitu 33\% tidak tahu manfaat ke dokter gigi, 26\% takut ke dokter gigi, 19\% merasa biaya ke dokter gigi mahal, 11\% tidak merasa butuh ke dokter gigi, dan 11 takut mengganggu janin. Setelah 9 hari intervensi, 19 responden dievaluasi consequence-nya dengan hasil $90 \%$ belum ke dokter gigi, $5 \%$ telah ke dokter gigi, dan $5 \%$ tidak mau ke dokter gigi. Alasan belum memeriksakan ke dokter gigi dikarenakan waktu $52 \%$, tidak ada yang mengantar $12 \%$, malas $12 \%$, takut ke dokter gigi $12 \%$, dan belum ada dana $12 \%$. Kesimpulan penelitian adalah perilaku pemeliharaan kesehatan gigi mulut ibu hamil didominasi pemeliharaan sendiri (sikat gigi dan kumur-kumur obat kumur), sementara pemeliharaan ke dokter gigi masih rendah dengan berbagai antecedence.
\end{abstract}

Maj Ked Gi Ind. Des 2015; 1(2): 201 - 207

Kata kunci: Perilaku ibu hamil, kehamilan, pemeliharaan kesehatan gigi dan mulut, pemeriksaan ke dokter gigi, antecedent-behavior-consequence

ABSTRACT: Maternal Behavior Change Program (Cerdigi) Based on ABC's Theory (Pilot Study in Serpong Subdistrict, South Tangerang). Oral health is one of the things that need attention during pregnancy. However, the behavior of dental and oral health maintenance during pregnancy is still low. Poor oral health conditions in pregnant women can have an impact, such as premature births and low birth weight (LBW) babies. ABC behavior change theory focuses on the antecedent, behavior, and consequence of behavior. The purpose of this study is to determine pregnant women's behavior of oral health maintenance, identify their antecedent factors, behavior change interventions (DHE), and analyze the behavior consequence. This was a descriptive research with a cross-sectional design among 27 pregnant women in Serpong Subdistrict, South Tangerang. The data were collected through interviews and questionnaires. The results show 100\% (27 respondents) did tooth brushing twice a day, 44,4\% (12 respondents) used mouthwash once a week and 4\% (1 respondent) visited a dentist during pregnancy. The antecedent factors of not visiting a dentist during pregnancy were because: $33 \%$ did not know the benefits of visiting a dentist, $26 \%$ had fear of dentist, $19 \%$ felt that visiting a dentist was expensive, $11 \%$ did not feel the need to go to a dentist, and $11 \%$ had fear of disturbing the fetus. After 9 days of intervention, the consequences on the 19 respondents were evaluated and the results show that $89.5 \%$ had not visited a dentist, $5.25 \%$ had visited a dentist, and $5.25 \%$ did not want to visit a dentist. The reason of not visiting a dentist was because of having not much time $52.8 \%$, having nobody to accompany $11.8 \%$, feeling lazy $11.8 \%$, still feeling afraid of a dentist $11.8 \%$, and having no money $11.8 \%$. The conclusion from this study is that the most dominant behaviors of oral health maintenance in pregnant women is to maintain it by themselves (toothbrushing and using mouthwash), while maintaining the health by visiting a dentist is still low with various antecendents.

Maj Ked Gi Ind. Des 2015; 1(2): 201 - 207

Keywords: Behavior of pregnant women, pregnancy, maintenance of oral health, dental examination, antecedentsbehavior-consequence 


\section{PENDAHULUAN}

Kesehatan gigi dan mulut merupakan salah satu hal yang perlu diperhatikan selama kehamilan, hal ini disebabkan karena wanita hamil merupakan salah satu kelompok yang rentan terhadap penyakit gigi dan mulut. Selama kehamilan terjadi proses perubahan alamiah yang dialami oleh ibu hamil, baik secara fisiologi, anatomi dan hormonal. Terutama pengaruh perubahan hormonal inilah yang dapat mempengaruhi hampir ke semua sistem organ, termasuk rongga mulut. ${ }^{1,2}$ Beberapa studi menyatakan bahwa lesi mukosa oral lebih sering terjadi pada wanita hamil daripada wanita yang tidak hamil, diantaranya mengalami gingivitis, epulis gravidarum dan granuloma piogenik. ${ }^{1,2,3}$

Hal termudah untuk mendapatkan kondisi rongga mulut yang sehat adalah dengan cara mencegah dan memelihara kesehatan gigi dan mulut. Namun, perilaku pemeliharaan kesehatan gigi dan mulut selama hamil yang dilakukan oleh ibu hamil masih rendah. Hasil penelitian yang dilakukan oleh Diana di Indonesia tahun 2009, menyebutkan bahwa hanya sedikit (38\%) wanita hamil yang mengetahui hubungan antara kehamilan dengan kesehatan gigi dan mulut. Selebihnya (43\%) wanita hamil menjawab tidak ada hubungan antara kehamilan dengan kesehatan gigi dan mulut. ${ }^{4}$ Hasil penelitian tersebut menunjukkan bahwa kurangnya pengetahuan dan perilaku wanita hamil terhadap pemeliharaan kesehatan gigi dan mulut. Kurangnya pemeliharaan kesehatan gigi dan mulut akan menyebabkan terjadinya penyakit gigi dan mulut. ${ }^{2,4}$

Perilaku pemeliharaan kesehatan gigi dan mulut dapat dilakukan secara mandiri di rumah (sikat gigi, kumur-kumur dengan air hangat atau obat kumur, flossing, dII) atau dengan melakukan pemeriksaan rutin ke dokter gigi selama kehamilan. Dengan melakukan pemeliharaan kesehatan gigi dan mulut, maka kondisi kesehatan gigi dan mulut ibu hamil akan optimal, hal ini sangat mempengaruhi asupan makanan yang masuk ke dalam janin., ${ }^{1,2}$ Kemauan untuk melakukan pemeliharaan kesehatan gigi dan mulut sangat dipengaruhi oleh pengetahuan akan pentingnya menjaga kesehatan gigi dan mulut. Penelitian oleh Mwaiswelo tahun 2007 menunjukkan hanya 16\% dari ibu hamil yang menerima pendidikan kesehatan gigi dan mulut, $97 \%$ dari ibu hamil menyikat giginya, dan $52 \%$ dari ibu hamil percaya menyikat gigi secara rutin akan mengurangi risiko terjadinya masalah pada gusi serta hanya $3,7 \%$ ibu hamil yang mengunjungi dokter gigi selama kehamilan. ${ }^{5}$

Kondisi masyarakat Indonesia, dalam hal ini khususunya wanita hamil, yang masih kurang kesadaran akan pemeliharaan kesehatan gigi dan mulut akan membuat kondisi kesehatan gigi dan mulut mereka bertambah buruk dibandingkan dengan kondisi sebelumnya. Kondisi kesehatan gigi dan mulut ibu hamil yang buruk dapat memberikan dampak, seperti bayi lahir prematur dan berat badan lahir rendah (BBLR). Penelitian oleh Santoso, dkk. tahun 2009 mengemukakan bahwa gingivitis yang tidak dirawat pada wanita hamil merupakan salah satu faktor risiko bayi dengan BBLR dan prematur, dengan hasil analisis data yang menunjukkan bahwa responden dengan kebersihan mulut kurang, memiliki risiko 2,55 kali melahirkan bayi dengan BBLR dan prematur dibandingkan dengan responden dengan kebersihan mulut yang baik. ${ }^{6}$

Model ABC atas perubahan perilaku merupakan gabungan dari 3 (tiga) elemen, yaitu antecedents, behaviour dan consequences (ABC). Menurut para pendukung model tersebut, perilaku sebetulnya dapat diubah dengan melalui 2 (dua) cara, yaitu berdasarkan apa yang mempengaruhi perilaku sebelum terjadi (ex-ante) dan apa yang mempengaruhi perilaku setelah terjadi (ex-post). Ketika kita mencoba mempengaruhi perilaku sebelum perilaku itu terbentuk berarti kita telah menggunakan antecedents. Sementara itu, ketika kita berusaha mempengaruhi perilaku dengan melakukan sesuatu setelah perilaku itu terbentuk berarti kita menggunakan consequences. Jadi sebuah antecedents mendorong terbentuknya perilaku yang selanjutnya akan diikuti oleh sebuah consequences. ${ }^{7,8}$ Perilaku dapat dipelajari dan diubah dengan cara mengidentifikasi dan memanipulasi keadaan suatu lingkungan yang mendahului (anteseden) serta yang mengikuti suatu perilaku (konsekuen). ${ }^{7}$ Elemen inti dari teori $\mathrm{ABC}$ adalah antecedent-behavior-consequences, yaitu sebuah perilaku dipicu oleh beberapa 
rangkaian peristiwa anteseden (sesuatu yang mendahului sebuah perilaku dan secara kausal terhubung dengan perilaku tersebut), kemudian sebuah perilaku diikuti oleh konsekuensi (hasil nyata dari perilaku yang dapat meningkatkan atau menurunkan kemungkinan perilaku tersebut untuk berulang kembali). ${ }^{7,8}$ Teori ini membantu mengidentifikasi cara mengubah perilaku dengan memastikan keberadaan anteseden yang tepat dan konsekuensi yang mendukung perilaku tersebut.

Program CERDIGI/Cerdas Peduli Kesehatan Gigi dan Mulut dibuat sebagai program perubahan perilaku ibu hamil, dalam hal ini perilaku pemeliharaan kesehatan gigi dan mulut, dengan memberikan pendidikan kesehatan gigi dan mulut (DHE/Dental Health Education) untuk meningkatkan pengetahuan dan kesadaran akan pentingnya kesehatan gigi dan mulut untuk kesehatan ibu hamil dan janinnya dengan pendekatan teori $A B C$, yaitu mengindentifikasi faktor antesenden dan konsekuensnya, sehingga perubahan perilaku menjadi lebih terarah dan diharapkan berlangsung lama serta menetap. Program ini diharapkan dapat memberikan perubahan positif perilaku kesehatan pada ibu hamil, yaitu perilaku pemeliharaan kesehatan gigi dan mulut, baik dilakukan sendiri maupun dengan melakukan kunjungan pemeriksaan kesehatan gigi dan mulut ke dokter gigi dan pelayanan kesehatan masyarakat terdekat. Program ini merupakan studi pendahuluan yang bertujuan untuk melihat gambaran awal permasalahan, pengaruh program dan mendapatkan feedback untuk evaluasi program yang lebih baik ke depannya.

Penelitian ini bertujuan melihat pengaruh program CERDIGI, dengan mengidentifikasi perilaku pemeliharaan kesehatan gigi dan mulut, kemudian mengidentifikasi anteseden dan konsekuensnya berdasarkan teori $\mathrm{ABC}$.

\section{METODE PENELITIAN}

Jumlah populasi sampel penelitian ini adalah 27 ibu hamil yang berada di Kelurahan Serpong, Tangerang Selatan. Pengambilan sampel penelitian ini adalah dengan menggunakan purposive sampling pada pemilihan lokasi kelurahan yaitu
Kelurahan Serpong, hal ini karena lokasi ini lebih mudah dijangkau oleh peneliti. Penelitian ini dilaksanakan pada bulan Mei - Juni 2015 di ruang pertemuan Puskesmas Kelurahan Serpong, Tangerang Selatan. Jenis penelitian yang digunakan adalah observasional deskriptif dengan desain cross sectional study. Pengumpulan data primer melalui wawancara langsung dengan responden menggunakan kuesioner yang telah ditetapkan, dengan sebelumnya responden diberikan inform consent untuk pemberian persetujuan bahwa responden mau mengikuti penelitian ini. Kuesioner dibagi 3 tahap, yang pertama kuesioner untuk mengetahui perilaku pemeliharaan kesehatan gigi dan mulut apa yang hendak diubah, kemudian selanjutnya tahap kedua kuesioner berisi pertanyaan-pertanyaan terkait faktor anteseden perilaku pemeliharaan kesehatan gigi dan mulut apa yang hendak diubah tersebut dan yang ketiga merupakan kuesioner tindak lanjut yaitu berisikan pertanyaan-pertanyaan mengenai faktor konsekuens perilaku pemeliharaan kesehatan gigi dan mulut apa yang hendak diubah tersebut. Kuesioner tahap 1 dan 2 diberikan dalam 1 hari yang sama, tanggal 23 Mei 2015 , sedangkan untuk kuesioner tahap 3 diberikan setelah 9 hari, yaitu tanggal 3 Juni 2015. Berdasarkan kuesioner tahap 1, perilaku pemeliharaan kesehatan gigi dan mulut apa yang hendak diubah didapatkan, kemudian kuesioner 2 diberikan untuk mengetahui anteseden perilaku tersebut, setelah diketahui faktor-faktor antesedent tersebut, masing-masing kelompok berdasarkan faktor antesedentnya diberikan intervensi berupa metode pendidikan kesehatan gigi dan mulut/DHE selama 30 menit. Kuesioner dan wawancara tahap 3 dilakukan setelah hasil evaluasi intervensi (feedback) didapatkan, dan pelaksanaan ini dilakukan secara door-to-door ke masing-masing rumah dari responden.

Kriteria inklusi pada penelitian ini yaitu ibu hamil dengan usia kehamilan lebih dari 2 minggu dan telah dinyatakan positif hamil oleh bidan atau dokter; telah berkunjung ke Posyandu, Kelas Ibu Hamil atau Poli KIA Puskesmas Serpong I saat penelitian dilakukan; ibu hamil di daerah kelurahan Serpong yang belum terjaring di Posyandu dan Puskesmas Serpong I; berdomisili tetap di 
kelurahan Serpong. Kriteria eksklusi pada penelitian ini yaitu ibu hamil yang tidak bersedia menjawab pertanyaan; ibu hamil yang tidak kooperatif/tidak dapat berkomunikasi dengan baik saat dilakukan wawancara; dan ibu hamil yang belum mengetahui secara pasti usia kehamilannya.

\section{HASIL PENELITIAN}

Hasil penelitian dari observasi perilaku pemeliharaan kesehatan gigi dan mulut sebanyak 27 responden ibu hamil di wilayah Kelurahan Serpong, Tangerang Selatan menunjukkan bahwa sebesar $100 \%$ (27 responden) telah menyikat gigi $2 x /$ hari, sebesar $44,4 \%$ (12 responden) telah menggunakan obat kumur $1 \mathrm{x} /$ minggu dan hanya $4 \%$ ( 1 responden) yang telah memeriksakan diri ke dokter gigi saat hamil (Tabel 1, 2 dan 3).

Tabel 1. Distribusi perilaku menyikat gigi $2 x /$ hari ibu hamil di Kelurahan Serpong, Tangerang Selatan

\begin{tabular}{ccc}
\hline Perilaku Menyikat Gigi 2x/hari & Jumlah & Persentase \\
\hline Ya & 27 & 100,0 \\
Tidak & 0 & 0,0 \\
Total & 27 & 100,0 \\
\hline
\end{tabular}

Tabel 2. Distribusi perilaku berkumur dengan obat kumur $1 \mathrm{x} /$ minggu ibu hamil di Kelurahan Serpong, Tangerang Selatan

\begin{tabular}{ccc}
\hline $\begin{array}{c}\text { Perilaku Berkumur dengan } \\
\text { Obat Kumur 1x/minggu }\end{array}$ & Jumlah & Persentase \\
\hline Ya & 12 & 44,4 \\
Tidak & 15 & 55,6 \\
Total & 27 & 100,0 \\
\hline
\end{tabular}

Tabel 3. Distribusi perilaku memeriksakan ke dokter gigi ibu hamil di Kelurahan Serpong, Tangerang Selatan

\begin{tabular}{ccc}
\hline $\begin{array}{c}\text { Perilaku Memeriksakan ke } \\
\text { Dokter Gigi }\end{array}$ & Jumlah & Persentase \\
\hline Ya & 1 & 4,0 \\
Tidak & 26 & 96,0 \\
Total & 27 & 100,0 \\
\hline
\end{tabular}

Hasil penelitian dari faktor anteseden perilaku tidak memeriksakan ke dokter gigi saat hamil menunjukkan bahwa sebesar 33\% (9 responden) karena tidak tahu manfaat ke dokter gigi, sebesar $26 \%$ (7 responden) karena takut ke dokter gigi, sebesar $19 \%$ (5 responden) karena merasa biaya ke dokter gigi mahal, sebesar 11\% (3 responden) karena tidak merasa butuh ke dokter gigi, dan sebesar $11 \%$ (3 responden) karena takut mengganggu janin (Tabel 4).

Tabel 4. Distribusi Faktor antesedent perilaku tidakmemeriksakan ke dokter gigi ibu hamil di Kelurahan Serpong,Tangerang Selatan

\begin{tabular}{ccc}
\hline $\begin{array}{c}\text { Faktor Antesedent Perilaku Tidak } \\
\text { Memeriksakan ke Dokter Gigi }\end{array}$ & Jumlah & Persentase \\
\hline Tidak tahu manfaat ke dokter gigi & 9 & 33,0 \\
Takut ke dokter gigi & 7 & 26,0 \\
Biaya ke dokter gigi mahal & 5 & 19,0 \\
Tidak merasa butuh ke dokter gigi & 3 & 11,0 \\
Takut mengganggu janin & 3 & 11,0 \\
Total & 27 & 100,0 \\
\hline
\end{tabular}

Sejumlah 19 responden yang dapat melanjutkan indentifikasi konsekuens perilakunya, namun sebelumnya hasil evaluasi intervensi menunjukkan yaitu sebesar $90 \%$ (17 responden) belum ke dokter gigi, sebesar $5 \%$ (1 responden) telah ke dokter gigi, dan sisanya sebesar $5 \%$ (1 responden) tidak mau ke dokter gigi (Tabel 5). Hasil identifikasi faktor konsekuensnya (alasan belum memeriksakan ke dokter gigi) disebabkan oleh faktor waktu sebesar $52 \%$ ( 9 responden), faktor tidak ada yang mengantar sebesar $12 \%$ (2 responden), faktor malas sebesar $12 \%$ (2 responden), faktor masih takut ke dokter gigi sebesar $12 \%$ (2 responden), dan faktor belum ada dana sebesar $12 \%$ (2 responden) (Tabel 6 ).

Tabel 5. Distribusi hasil evaluasi intervensi DHE pada ibu hamil di Kelurahan Serpong, Tangerang Selatan

\begin{tabular}{ccc}
\hline Evaluasi Intervensi DHE & Jumlah & Persentase \\
\hline Belum ke dokter gigi & 17 & 90,0 \\
Telah ke dokter gigi & 1 & 5,0 \\
Tidak mau ke dokter gigi & 1 & 5,0 \\
Total & 19 & 100,0 \\
\hline
\end{tabular}

Tabel 6. Distribusi faktor konsekuens perilaku tidak memeriksakan ke dokter gigi ibu hamil di Kelurahan Serpong, Tangerang Selatan

\begin{tabular}{ccc}
\hline $\begin{array}{c}\text { Faktor Konsekuens Perilaku Tidak } \\
\text { Memeriksakan ke Dokter Gigi }\end{array}$ & Jumlah & Persentase \\
\hline Tidak ada waktu & 9 & 52,0 \\
Tidak ada yang mengantar ke dokter gigi & 2 & 12,0 \\
Malas ke dokter gigi & 2 & 12,0 \\
Masih takut ke dokter gigi & 2 & 12,0 \\
Belum ada dana & 2 & 12,0 \\
Total & 19 & 100,0 \\
\hline
\end{tabular}




\section{PEMBAHASAN}

Hasil penelitian menunjukkan 100\% responden menyikat gigi 2x/hari, $44,4 \%$ menggunakan obat kumur $1 \mathrm{x} /$ minggu dan $4 \%$ memeriksakan ke dokter gigi saat hamil. Hasil penelitian tersebut menjelaskan bahwa perilaku pemeliharaan kesehatan gigi ibu hamil sudah cukup baik dilaksanakan secara mandiri di rumah seperti sikat gigi $2 x$ sehari, sebagian besar juga telah menggunakan obat kumur $1 \mathrm{x}$ seminggu, namun dari 27 responden hanya 1 orang ibu hamil yang telah memeriksakan diri ke dokter gigi saat hamil. Hasil penelitian ini sesuai dengan penelitian yang dilakukan oleh Marchi dkk, menunjukkan bahwa $65 \%$ ibu hamil di California tidak melakukan pemeriksaan ke dokter gigi, walaupun sebagian besar (52\%) ibu hamil tersebut dilaporkan memiliki masalah gigi dan mulut selama kehamilan. ${ }^{9}$

Berdasarkan data hasil penelitian diatas, peneliti kemudian mengidentifikasi faktor anteseden apa saja yang melatarbelakangi perilaku tidak memeriksakan ke dokter gigi saat hamil dan selanjutnya menindaklanjuti dengan mengidenitifikasi faktor konsekuens apa yang mengikuti perilaku tidak memeriksakan kesehatan gigi dan mulut selama hamil tersebut. Dari hasil penelitian, terungkap bahwa faktor anteseden tidak memeriksakan ke dokter gigi saat hamil, yaitu 33\% karena tidak tahu manfaat ke dokter gigi, $26 \%$ karena takut ke dokter gigi, 19\% karena merasa biaya ke dokter gigi mahal, $11 \%$ karena tidak merasa butuh ke dokter gigi, dan $11 \%$ karena takut mengganggu janin. Penelitian dari Bianca (2009), mendukung hasil penelitian tersebut, bahwa selama kehamilan sebanyak lebih dari $60 \%$ wanita dilaporkan memiliki penyakit gigi dan mulut, yaitu gingivitis, namun hanya $32 \%$ wanita yang pergi ke dokter gigi selama kehamilan, dan kurang dari setengahnya yang memiliki akses informasi mengenai kesehatan gigi dan mulut yang berhubungan dengan kehamilan. Wanita hamil yang pergi ke dokter gigi selama kehamilannya akan memperbesar kemungkinan untuk menerima informasi tentang kesehatan gigi dan mulut, sehingga diharapkan terjadi peningkatan pengetahuan dan kesadaran akan kesehatan gigi dan mulut selama hamil. ${ }^{10}$
Setelah 9 hari dilakukan intervensi (metode $\mathrm{DHE}$ ), dengan pendekatan pemberian edukasi sesuai dengan masing-masing antesendennya, sejumlah 19 responden yang dapat dilanjutkan indentifikasi konsekuensnya. Hasilnya adalah 90\% masih belum ke dokter gigi, $5 \%$ telah ke dokter gigi, dan sisanya sebanyak $5 \%$ tidak mau ke dokter gigi. Dari hasil tersebut terlihat bahwa konsekuens yang mengikuti perilaku adalah lebih bersifat melemahkan perilaku. Hal ini sesuai dengan pernyataan Graeff dkk, yang mengungkapkan bahwa secara umum, seseorang akan cenderung mengulangi perilaku-perilaku yang membawa hasil positif dan akan cenderung menghindari perilaku yang memberikan hasil negatif. ${ }^{7}$ Pernyataan Graeff dkk ini berkesesuaian dengan hasil penelitian dari hasil identifikasi faktor konsekuensnya, yaitu alasan belum mereka memeriksakan ke dokter gigi disebabkan oleh faktor waktu sebesar $52 \%$, faktor tidak ada yang mengantar sebesar $12 \%$, faktor malas sebesar $12 \%$, faktor masih takut ke dokter gigi sebesar $12 \%$, dan faktor belum ada dana sebesar $12 \%$. Hasil ini memperlihatkan bahwa diperlukan usaha besar yang harus mereka lakukan untuk membentuk perilaku memeriksakan kesehatan gigi dan mulut mereka ke dokter gigi, misalnya meluangkan waktu, mengeluarkan sejumlah dana, mengalahkan rasa takut dan rasa malas, dan mengikutsertakan orang lain untuk mengantarkan mereka ke dokter gigi untuk memeriksakan kesehatan gigi dan mulut mereka.

Adanya pemberian program perubahan perilaku ibu hamil (CERDIGI) sebagai penelitian pendahuluan yang melihat gambaran permasalahan di sebuah komunitas kecil di wilayah Puskesmas Kelurahan Serpong, diharapkan upaya peningkatan kesehatan gigi dan mulut ibu hamil lebih terarah dan tepat sasaran karena dapat sesuai dengan masing-masing antesenden/faktor pemicu sebuah perilaku dan dapat memperkuat konsekuens secara positif dari perilaku tersebut. Sesuai dengan pernyataan Roughton, bahwa sebuah konsekuens perilaku yang merupakan penguatan positif dapat berupa hal yang diinginkan, seperti penghargaan, kenyamanan, penghematan waktu. Menurut Fleming \& Lardner, diperlukan beberapa strategi 
yang dapat digunakan untuk penguatan positif konsekuensi dari sebuah perilaku, yaitu dengan melibatkan target individu atau kelompok dalam menentukan konsekuensi dan memperhatikan apa yang dipilih target individu atau kelompok untuk dilakukan, jadi tidak memaksakan perilaku yang kurang atau belum diinginkan.

Krausse (1996) dalam Dwinanda \& Bayu (2007) menyatakan bahwa kekuatan sebuah konsekuens dalam mempengaruhi sebuah perilaku ditentukan oleh 3 hal: (1) waktu, yaitu konsekuens yang mengikuti segera akan berpengaruh lebih kuat; (2) konsistensi, yaitu konsistensi akan lebih memastikan konseskuens mengikuti sebuah perilaku; dan (3) signifikansi, konsekuens positif dan signifikan akan lebih kuat daripada konsekuensi negatif dan non-signifikan.

Peningkatan pengetahuan, kesadaran dan perilaku memelihara kesehatan gigi dan mulut saat hamil, akan berdampak dalam pencapaian Millennium Development Goals (MDGs) tujuan ke-5 yaitu meningkatkan kesehatan ibu hamil dimana kesehatan gigi dan mulut merupakan salah satu aspek penting yang perlu diperhatikan untuk menurunkan risiko kelahiran bayi prematur dan berat badan lahir rendah.

Kesehatan ibu hamil perlu secara komprehensif, bukan hanya kesehatan secara umum ibu hamil dan janin saja yang dipentingkan, namun juga harus dibarengi dengan peningkatan kesehatan gigi dan mulut ibu hamil, yang juga akan berdampak untuk kesehatan janin. Kerjasama dengan petugas kesehatan lain, seperti bidan, dokter umum atau dokter spesialis kandungan untuk ikut serta memberikan rujukan dan rekomendasi untuk melakukan pemeriksaan kesehatan gigi dan mulut ibu hamil sangat diperlukan. Upaya preventif seperti ini sangat baik untuk memberikan pengetahuan, kesadaran akan pentingnya kesehatan gigi dan mulut selama kehamilan.

\section{KESIMPULAN}

Program perubahan perilaku ibu hamil (CERDIGI) di Kelurahan Serpong, Tangerang
Selatan menunjukkan masih rendahnya (4\%) perilaku pemeliharaan kesehatan gigi mulut ibu hamil ke dokter gigi, dengan berbagai antesedensnya yang didominasi karena tidak tahu manfaat ke dokter gigi $(33 \%)$, oleh karenanya kesadaran untuk memelihara kesehatan gigi dan mulut juga akan rendah, sehingga dibutuhkan intervensi untuk perubahan perilaku dengan memberikan edukasi (DHE). Intervensi akan tepat dan sesuai jika kita mengetahui secara pasti faktor antesedent dan konsekuens perilaku. Antecedents tanpa diikuti consequences mempunyai dampak jangka pendek. Konsekuens perilaku pemeliharaan kesehatan gigi mulut ibu hamil ke dokter gigi menunjukkan konsekuens yang negatif (mayoritas: waktu 52\%), sehingga untuk membentuk perubahan perilaku yang menetap, konsekuens ini harus diatur sedemikian rupa sehingga cukup waktu untuk memeriksakan kesehatan gigi dan mulut ke dokter gigi selama hamil, sehingga risiko-risiko buruk yang terkait kehamilan dan persalinan akibat kesehatan gigi dan mulut dapat terhindarkan.

\section{DAFTAR PUSTAKA}

1. Ekaputri N, Sjahruddin FLD. Hubungan perilaku wanita hamil dalam membersihkan gigi dan mulut dengan kedalaman poket periodontal selama masa kehamilan. M I Kedokteran Gigi. 2005; 62: 90-2.

2. Hajikazemi E, Fateme $O$, Shoaleh HM, Soghra N, Hamid $\mathrm{H}$. The relationship between knowledge, attitude, and practice of pregnant women about oral and dental care. Euro J. 2008; 24 (4): 556-61.

3. Sarifakioglu E, Gunduz C, Gorpelioglu. Oral mucosa manifestations in 100 pregnant versus non-pregnant patients: an epidemiological observational study (abstract). EDJ. 2006; 16 (6): 674 .

4. Diana D. Pengetahuan, sikap, dan perilaku wanita hamil pengunjung poli ibu hamil (PIH) RSUD dr. Pirngadi Medan terhadap kesehatan gigi dan mulut selama masa kehamilan periode November-Desember 2009. Skripsi. Medan: FKG USU; 2009. H. 42-7. 
5. Mwaiswelo RO, Masalu JR. Oral health knowledge and behavior among pregnant women in Keyla District, Mabeya, Tanzania. Tanzania dent J. 2007; 14 (2): 47-52.

6. Santoso O, Wildam ASR, Retroningrum D. Hubungan kebersihan mulut dan gingivitis ibu hamil terhadap kejadiaan bayi berat badan lahir rendah kurang bulan di RSUP Dr. Kariadi Semarang dan jejaringanya. Media Medika Indonesiana. 2009; 43: 288-93.

7. Graeff JA, Elder JP, Booth EM. Communication for oral health and behavior change. San Fransisco: Jossey-Bass Publishers; 1996. H. 27-36.
8. Potoczak K, Carr JE, Michael J. The effects of consequence manipulation during functional analysis of problem behavior maintained by negative reinforcement. Applied Behavior Analysis J. 2007; 40: 719-724.

9. Marchi KS, Fisher Owe SA, Weintraub JA, Yu $Z$, Braveman PA. Most pregnant women in California do not receive dental care: findings from a population-based study. Public Health Rep J. 2010; 125(6): 831-42.

10. Claas BM. Self-reported oral health and access to dental care among pregnant women In Wellington. Thesis. Wellington, New Zealand: Master of Public Health at Massey University; 2009. H. 15-8. 